\title{
Właściwości materiałów dodatkowych do spawania stali P92 stosowanych do budowy bloków na parametry super nadkrytyczne
}

\section{Properties of T/P92 steel weld metal for ultra super critical power plants}

\section{Streszczenie}

Europejskie regulacje $w$ zakresie obniżania emisji szkodliwych gazów do atmosfery mają decydujący wpływ na wymagania stawiane współczesnej energetyce. Poszukiwania efektywnych rozwiązań w zakresie ograniczenia emisji szkodliwych gazów do atmosfery stanowią od wielu lat największe wyzwanie dla współczesnej energetyki, jak również inżynierii materiałowej. Znaczny postęp w tym zakresie dokonał się wraz z wprowadzeniem nowego gatunku stali o 9\% zawartości chromu typu T/P91, oraz w kolejnych latach także nowej generacji stali Cr-Mo, w tym charakteryzującą się $25 \div 30 \%$ wyższą odpornością na pełzanie stali T/P92. Wyższa odporność na pełzanie stali P92 umożliwia zastosowanie wyższych wartości parametrów pracy bloku do poziomu parametrów supernadkrytycznych. W artykule przedstawiono najważniejsze informacje na temat charakterystycznych przemian fazowych, doboru materiałów dodatkowych, jak również wpływu parametrów spawania i obróbki cieplnej na udarność.

\section{Abstract}

In order to achieve higher efficiencies and reduce emissions of environmentally damaging gases, new power generation technology requires high pressure and high temperature parameters. These have directly resulted in the introduction of ultra super critical (USC) plant and applications of a series of advanced Cr-Mo creep resistant steels. Among these newly developed ferritic steels, T/P92 has creep strength $25 \div 30 \%$ higher than the currently widely used modified $9 \% \mathrm{Cr}$ steel T/P91 and has been specified as one of the major alloys for the construction of USC plant. The present paper summarises the important phase transformation characteristics and properties of matching filler metals for T/P92 steel and discusses factors that influence the performance of these weld metals.

\section{Wstęp}

Węgiel jest ciągle najczęściej stosowanym paliwem w energetyce zawodowej nie tylko w Polsce, ale również w wielu krajach Europy i świata. Konwencjonalne

Zhuyao Zhang, Graham Holloway, Adam Marshall - Metrode Products Ltd., Wielka Brytania. bloki energetyczne opalane węglem emitują do atmosfery znacznie więcej szkodliwych gazów, tj. $\mathrm{CO}_{2}, \mathrm{NO}_{\mathrm{x}}$ i $\mathrm{SO}_{\mathrm{x}}$ w porównaniu do elektrowni opartych na innych technologiach. Od wielu lat celem nadrzędnym dla współczesnej energetyki konwencjonalnej jest projektowanie bloków o jak najwyższej sprawności, co związane jest bezpośrednio z podniesieniem parametrów pracy kotła do możliwie jak najwyższych poziomów temperatury i ciśnienia pary w kotle. Większa sprawność bloków oznacza zmniejszenie zużycia paliwa, 
jak również, co jest sprawą najważniejszą z punktu widzenia europejskiej polityki proekologicznej, ograniczenie emisji szkodliwych gazów do atmosfery.

Poszukiwania efektywnych rozwiązań w zakresie ograniczenia emisji szkodliwych gazów do atmosfery stanowią od wielu lat największe wyzwanie dla współczesnej energetyki, a w konsekwencji również dla inżynierii materiałowej. Znaczny postęp w tym obszarze dokonał się w latach dziewięćdziesiątych dzięki zastosowaniu nowego gatunku stali o $9 \%$ zawartości chromu T/P91, co umożliwiło znaczne, jak na ówczesne czasy, podwyższenie parametrów pracy kotła do temperatury pary na poziomie $580^{\circ} \mathrm{C}$ przy ciśnieniu 280 bar [1]. Prace badawcze w kolejnych latach zaowocowały nową generacją stali Cr-Mo, w tym głównie opracowaniem T/P92, który w porównaniu do T/P91 charakteryzuje się $25 \div 30 \%$ wyższą odpornością na pełzanie, możliwe stało się więc podwyższenie parametrów pracy bloku do poziomu parametrów supernadkrytycznych o temperaturze pary $610-620^{\circ} \mathrm{C}$

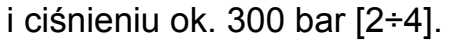

Pełne wykorzystanie tego gatunku oraz osiągnięcie najwyższych możliwych parametrów pracy elementów kotłów wykonanych ze stali T/P92 wymaga zastosowania odpowiednich materiałów dodatkowych do spawania, których skład chemiczny stopiwa odpowiada składowi chemicznemu materiału podstawowego.

W artykule zaprezentowano założenia do projektowania materiałów dodatkowych do spawania stali T/P92, zakresy temperatury najważniejszych przemian fazowych, w tym temperaturę austenityzacji $A_{c 1}$ oraz początku i końca przemiany martenzytycznej podczas chłodzenia $\left(\mathrm{M}_{\mathrm{s}} / \mathrm{M}_{\mathrm{f}}\right)$, jak również wpływ poszczególnych pierwiastków stopowych na $A_{c 1}, M_{s} / M_{f}$. W oparciu o wyniki badań w zakresie charakterystycznych przemian fazowych zaproponowano wytyczne doboru parametrów spawania i podano wskazówki dotyczące obróbki cieplnej po spawaniu, następnie przedstawiono ich wpływ na twardość oraz poziom udarności stopiwa w temperaturze otoczenia. W ostatniej części zaprezentowano wyniki badań czasowej wytrzymałości na pełzanie poparte badaniami eksploatacyjnymi złączy wykonanych ze stali T/P92.

\section{Materiały dodatkowe do spawania, wytyczne do projektowania składu chemicznego}

Zarówno przepisy ASME/AWS, jak i normy europejskie EN nie klasyfikują materiałów dodatkowych do spawania stali T/P92, z tego powodu podstawą do projektowania stopiwa materiałów spawalniczych jest skład chemiczny materiału podstawowego oraz wytyczne norm klasyfikacyjnych dla materiałów dodatkowych do spawania stali T/P91. Skład chemiczny stopiwa materiałów spawalniczych jest dobierany w sposób umożliwiający uzyskanie struktury w pełni martenzytycznej bez lub $z$ niewielkim udziałem ferrytu $\delta$, tak aby zapewnić jak najlepszą kombinację właściwości - odporności na pełzanie i udarności w temperaturze otoczenia. Typowy skład chemiczny stopiwa materiałów dodatkowych do spawania stali T/P92 pokazano w tablicy I.

Opisano wpływ najważniejszych pierwiastków stopowych na udarność i wytyczne do projektowania składu chemicznego.

Nb. Wyniki badań pokazują, że zarówno dla materiałów spawalniczych T/P91, jak i T/P92 niższym zawartościom niobu w stopiwie towarzyszy wyższa udarność. $Z$ tego powodu zawartość $\mathrm{Nb}$ utrzymywana jest w jak najniższym możliwym zakresie określonym dla materiału podstawowego. W przypadku stali T/P92 najodpowiedniejszy jest zakres $0,04 \div 0,05 \%$. W przypadku drutów pełnych maksymalna zawartość niobu wynosi $0,06 \%$. Dla metody TIG, która z natury zapewnia wyższą udarność, zawartość niobu może być nieznacznie wyższa. Podobnie w przypadku kombinacji SAW drut-topnik zawartość niobu w drucie może być nieco większa od zalecanej. Jest to możliwe, ponieważ podczas spawania zawartość niobu jest redukowana do poziomu zalecanych $0,04 \div 0,05 \%$.

Ni. Nikiel jest niezastąpionym składnikiem stopowym poprawiającym udarność, ponieważ obniża temperaturę austenityzacji $A_{c 1}$, co zwiększa skuteczność obróbki cieplnej po spawaniu, i zmniejsza tendencję do wydzielania się niepożądanego $\mathrm{w}$ tym przypadku

Tablica I. Skład chemiczny stali T/P92 oraz materiałów dodatkowych [5]

Table. I. Typical T/P92 weld metal deposit compositions (wt\%) [5]

\begin{tabular}{|c|c|c|c|c|c|c|c|c|c|c|c|c|c|c|}
\hline Składnik stopowy & C & $\mathrm{Mn}$ & $\mathrm{Si}$ & $\mathrm{S}$ & $\mathrm{P}$ & $\mathrm{Cr}$ & $\mathrm{Ni}$ & Mo & W & $\mathrm{Nb}$ & V & $\mathrm{N}$ & $\mathrm{Al}$ & B \\
\hline P92 min. & 0,07 & 0,30 & - & - & - & 8,50 & - & 0,30 & 1,50 & 0,04 & 0,15 & 0,030 & - & 0,001 \\
\hline P92 max. & 0,13 & 0,60 & 0,50 & 0,010 & 0,020 & 9,50 & 0,40 & 0,60 & 2,00 & 0,09 & 0,25 & 0,070 & 0,040 & 0,006 \\
\hline TIG/SAW drut ${ }^{a}$ & 0,11 & 0,71 & 0,29 & 0,008 & 0,009 & 9,0 & 0,5 & 0,5 & 1,7 & 0,06 & 0,20 & 0,05 & $<0,01$ & 0,003 \\
\hline TIG stopiwo & 0,10 & 0,70 & 0,23 & 0,006 & 0,007 & 9,0 & 0,5 & 0,5 & 1,7 & 0,05 & 0,17 & 0,04 & $<0,01$ & 0,002 \\
\hline MMA stopiwo b & 0,11 & 0,60 & 0,25 & 0,008 & 0,008 & 9,0 & 0,6 & 0,5 & 1,7 & 0,05 & 0,20 & 0,05 & $<0,01$ & 0,003 \\
\hline FCAW stopiwo $^{c}$ & 0,11 & 0,80 & 0,29 & 0,006 & 0,017 & 9,0 & 0,5 & 0,5 & 1,7 & 0,04 & 0,20 & 0,04 & $<0,01$ & 0,003 \\
\hline SAW stopiwo $^{d}$ & 0,10 & 0,76 & 0,29 & 0,005 & 0,010 & 8,8 & 0,5 & 0,5 & 1,7 & 0,04 & 0,17 & 0,04 & 0,015 & 0,001 \\
\hline \multicolumn{15}{|c|}{$\begin{array}{l}\text { a Skład chemiczny drutu pełnego TIG/SAW } \\
\text { b Skład chemiczny stopiwa elektrod MMA } \\
\text { c Skład chemiczny stopiwa drutu proszkowego FCAW } \\
\text { d Skład chemiczny stopiwa wykonanego łukiem krytym SAW }\end{array}$} \\
\hline
\end{tabular}


ferrytu $\delta . Z$ drugiej strony trzeba pamiętać, że zbyt wysoka zawartość Ni powyżej 1\% jest dla materiałów typu Cr-Mo bardzo szkodliwa. Jest to związane głównie ze znacznym obniżeniem temperatury $A_{c 1}$ poniżej zalecanego poziomu temperatury obróbki cieplnej (odpuszczania), co w czasie chłodzenia sprzyja wtórnemu formowaniu się świeżego nieodpuszczonego martenzytu. Poza tym nadmierna zawartość niklu w stopiwie obniża tak ważną dla tej grupy materiałów odporność na pełzanie w wysokiej temperaturze. Z wymienionych powodów zawartość niklu powinna oscylować wokół poziomu 0,5\%.

Co. Badania potwierdzają, że kobalt podobnie jak nikiel pozytywnie oddziałuje na poziom udarności stopiwa, przy nieznacznym wpływie na temperaturę $A_{c 1}$.

Mn. Mangan jest skutecznym pierwiastkiem odtleniającym oraz rafinującym materiał spoiny. $Z$ tego powodu zaleca się, aby zawartość Mn była utrzymywana w górnych dopuszczalnych zakresach. Należy jednak pamiętać, że mangan podobnie jak nikiel obniża temperaturę $A_{c 1}$, co zwiększa ryzyko formowania się austenitu wtórnego przy wyższej temperaturze obróbki cieplnej. Z tego powodu zaleca się, aby, tak jak w przypadku T/P91, sumaryczna zawartość $\mathrm{Ni}+\mathrm{Mn}$ nie przekraczała $1,5 \%$.

Si. Jest podstawowym składnikiem odtleniającym i w połączeniu z chromem przyczynia się, w niewielkiej mierze, do poprawy właściwości żaroodpornych. $Z$ drugiej strony znany jest negatywny wpływ krzemu na udarność. $Z$ tego powodu zakres zalecany dla tego składnika stopowego to $0,2 \div 0,3 \%$.

\section{Temperatury przemian fazowych stopiwa wybranych materiałów dodatkowych do spawania stali T/P92}

W przypadku stali energetycznych typu Cr-Mo w celu określenia odpowiednich parametrów spawania należy posłużyć się charakterystykami przemian fazowych dla wybranego gatunku stali. Temperatury przemian fazowych dla stali T/P92 w warunkach kontrolowanego nagrzewania i chłodzenia kształtują się następująco $[3,7]$ :

- temperatura austenityzacji $\mathrm{A}_{\mathrm{c} 1}=840 \div 845^{\circ} \mathrm{C}$,

- temperatura początku przemiany martenzytycznej $\mathrm{M}_{\mathrm{s}}=400^{\circ} \mathrm{C}$,

- temperatura końca przemiany martenzytycznej $\mathrm{M}_{\mathrm{f}}=200^{\circ} \mathrm{C}$.

Obecnie do pomiaru temperatury przemian fazowych szerokie zastosowanie znajdują techniki dylatometryczne, którymi posłużono się również przy prowadzeniu badań własnych. Dokonano pomiaru charakterystycznych temperatur $A_{c 1}, M_{s} i M_{f}$ dla materiału spoin wykonanych $z$ wykorzystaniem elektrod otulonych, drutów rdzeniowych oraz kombinacji drut-topnik. W tym celu próbki do badań zostały nagrzane do temperatury $1100^{\circ} \mathrm{C}$, a następnie przetrzymane $\mathrm{w}$ tej temperaturze przez dwie minuty $\mathrm{w}$ celu uzyskania jednorodnej struktury austenitycznej. Pomiarów temperatur $M_{s}$ i $M_{f}$ początku i końca przemiany martenzytycznej dokonywano przy dwóch różnych prędkościach chłodzenia 20 i $50^{\circ} \mathrm{C} / \mathrm{s}$, które reprezentują typową prędkość chłodzenia dla procesu spawania w zakresie temperatury $800 \div 500^{\circ} \mathrm{C}$.

\section{Wpływ składników stopowych na temperaturę $A_{c 1}$}

Wyniki pomiaru temperatury $A_{c 1}$ zostały zestawione na rysunku 1 , na którym obok danych dla poszczególnych materiałów dodatkowych pokazano również dane dla obu materiałów podstawowego T/P91 i T/P92 $[3,8]$. Zaobserwowano, że dla T/P92 wyniki pomiarów temperatury $A_{c 1}$ mieszczą się $w$ zakresie $800 \div 815^{\circ} \mathrm{C}$. $W$ przypadku materiału podstawowego temperatura $A_{c 1}$ stali T/P92 jest wyższa od $A_{c 1}$ dla T/P91. Podobnie wyniki pomiarów temperatury $A_{c 1}$ dla stopiwa materiałów dodatkowych wykazują ten sam trend. Dla tej samej zawartości pierwiastków $\mathrm{Ni}+\mathrm{Mo}$, temperatura $\mathrm{A}_{\mathrm{c} 1}$ stopiwa T/P92 jest o $5 \div 10^{\circ} \mathrm{C}$ wyższa od uzyskanej dla stopiwa T/P91 [9].

Wraz ze wzrostem zawartości $\mathrm{Ni}+\mathrm{Mn}$ w stopiwie temperatura $A_{c 1}$ ulega obniżeniu. Dla $\mathrm{Ni}+\mathrm{Mn}=1,5 \%$ temperatura $A_{c 1}$ wynosi $790^{\circ} \mathrm{C}$. Powyżej $1,5 \%$ temperatura $A_{c 1}$ obniża się znacznie w sposób nieliniowy, aby dla $\mathrm{Ni}+\mathrm{Mn}=2 \%$ obniżyć się aż do poziomu $735^{\circ} \mathrm{C}$. Gwałtowny spadek temperatury $A_{c 1}$ wraz ze wzrostem wskaźnika $\mathrm{Ni}+\mathrm{Mn}$ powyżej 1,5\% dowodzi, jak ważna jest ścisła kontrola zawartości tych dwóch składników w stopiwie materiału T/P92. Większość dostępnych informacji na temat stali T/P91 określa maksymalną zawartość $\mathrm{Ni}+\mathrm{Mn}$ na poziomie 1,5\%. Odnosząc ten warunek również do stali T/P92, można w łatwy sposób określić maksymalną temperaturę obróbki cieplnej po spawaniu. Dla granicznej wartości $\mathrm{Ni}+\mathrm{Mn}=1,5 \%$ temperatura $\mathrm{A}_{\mathrm{c} 1}$ wynosi $790^{\circ} \mathrm{C}$, którą następnie należy pomniejszyć o temperaturowy współczynnik bezpieczeństwa $-15^{\circ} \mathrm{C}$. W ten sposób

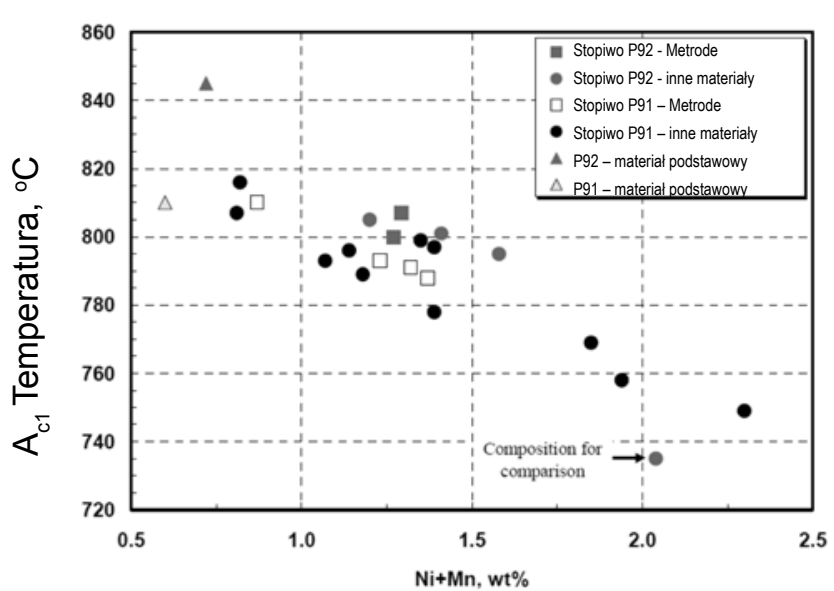

Rys. 1. Temperatura $A_{c 1}$ stopiwa P92 i P91 w zależności od zawartości $\mathrm{Ni}+\mathrm{Mn}$.

Fig. 1. $A_{c 1}$ temperatures of P92 and P91 weld metals and the effect of $\mathrm{Ni}+\mathrm{Mn}$ content 
otrzymuje się maksymalną dopuszczalną temperaturę obróbkicieplnejna poziomie $775^{\circ} \mathrm{C}$. Jakwidać, wyliczona wartość jest nieznacznie większa od $760^{\circ} \mathrm{C}$ zalecanych dla T/P91 (przy tym samym ograniczeniu zawartości $\mathrm{Ni}+\mathrm{Mn}=1,5 \%)$.

W związku ze znacznym wpływem niklu na temperaturę $A_{c 1}$ dąży się do jego ograniczenia w stopiwie materiałów dodatkowych T/P92. Znany jest jednak dobroczynny wpływ niklu na udarność, dlatego w praktyce nikiel w stopiwie T/P92 zastępowany jest w części lub nawet w całości dodatkiem kobaltu, który również poprawia i wyraźnie stabilizuje udarność w temperaturze otoczenia. Na podstawie dotychczasowych badań zaobserwowano nieznaczny, w porównaniu do niklu i manganu, wpływ kobaltu na obniżenie temperatury $A_{c 1}$, co zostało pokazane na rysunku 2 . Inne badania przeprowadzone dla stali typu $12 \%$ Cr pokazują, że dla $1 \%$ dodatku kobaltu temperatura $A_{c 1}$ ulega obniżeniu o ok. $7^{\circ} \mathrm{C}[10]$.

Chociaż wpływ Co na obniżenie temperatury $A_{c 1}$ jest wyraźnie mniejszy niż Ni i Mn, jego zawartość również powinna być kontrolowana dla stali T/P92. Zaleca się, aby dla temperatury $A_{c 1}>790^{\circ} \mathrm{C}$ sumaryczna zawartość tych trzech pierwiastków wyrażona równaniem $\mathrm{Ni}+\mathrm{Mn}+0,4$ Co nie przekraczała 1,5\%. Dla $A_{c 1}=800^{\circ} \mathrm{C}$ zawartość pierwiastków $\mathrm{Ni}+\mathrm{Mn}+0,4 \mathrm{Co}$ jest ograniczona do 1,4\% (rys. 3 ).

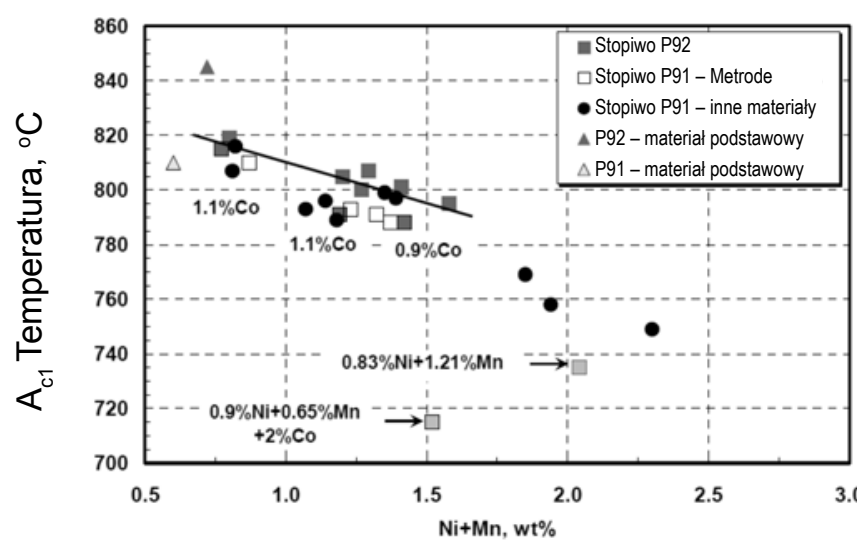

Rys. 2. Wpływ Ni i $\mathrm{Mn}$ na temperaturę $A_{c 1}$ stopiwa P92

Fig. 2. Effect of $\mathrm{Ni}$ and $\mathrm{Mn}$ on $\mathrm{A}_{\mathrm{c} 1}$ temperature of P92 weld metals

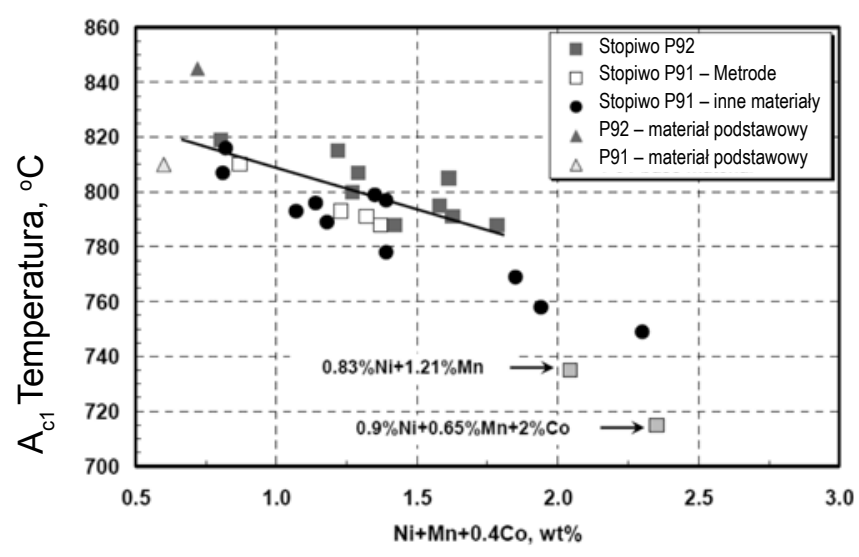

Rys. 3. Wpływ Ni, Mn i Co na temperaturę $A_{c 1}$ stopiwa P92

Fig. 3. Effect of $\mathrm{Ni}, \mathrm{Mn}$ and $\mathrm{Co}$ on $\mathrm{A}_{\mathrm{c1}}$ temperature of $\mathrm{P} 92$ weld metals
Tablica II. Temperatura początku i końca przemiany martenzytycznej $\left(M_{s}, M_{f}\right)$ stopiwa P91 i P92

Table II. Martensitic transformation temperatures $\left(M_{s}\right.$ and $\left.M_{f}\right)$ of $P 91$ and P92 weld metals

\begin{tabular}{|c|c|c|c|c|c|}
\hline \multirow{2}{*}{$\begin{array}{c}\text { Ga- } \\
\text { tunek } \\
\text { stali }\end{array}$} & $\begin{array}{c}\text { Proces } \\
\text { spawa- } \\
\text { nia }\end{array}$ & $\begin{array}{c}\text { Prędkość chłodzenia } \\
20^{\circ} \mathrm{C} / \mathrm{s}\end{array}$ & \multicolumn{2}{|c|}{$\begin{array}{r}\text { Prędkość chłodzenia } \\
50^{\circ} \mathrm{C} / \mathrm{s}\end{array}$} \\
\cline { 3 - 6 } & $\mathrm{M}_{\mathrm{s}},{ }^{\circ} \mathrm{C}$ & $\mathrm{M}_{\mathrm{f}},{ }^{\circ} \mathrm{C}$ & $\mathrm{M}_{\mathrm{s}},{ }^{\circ} \mathrm{C}$ & $\mathrm{M}_{\mathrm{f}},{ }^{\circ} \mathrm{C}$ \\
\hline \multirow{4}{*}{ P91 } & MMA & 402 & 167 & 407 & 128 \\
\cline { 2 - 6 } & SAW & 419 & 200 & 426 & 136 \\
\cline { 2 - 6 } & FCAW & 381 & 157 & 385 & 107 \\
\hline \multirow{3}{*}{ P92 } & MMA & 383 & 151 & 382 & 117 \\
\cline { 2 - 6 } & SAW & 385 & 147 & 388 & 105 \\
\cline { 2 - 6 } & FCAW & 382 & 127 & 371 & 105 \\
\hline
\end{tabular}

\section{Temperatury początku i końca przemiany martenzytycznej $M_{s}$ i $M_{f}$}

Na podstawie informacji podanych przez wytwórców materiałów podstawowych temperatura początku przemiany martenzytycznej $\mathrm{M}_{\mathrm{s}}$ dla T/P92 wynosi ok. $400^{\circ} \mathrm{C}$, natomiast koniec przemiany następuje w temperaturze $M_{f}$ równej ok. $200^{\circ} \mathrm{C}[3,7]$. W tablicy II pokazano wyniki pomiaru temperatur $M_{s}$ i $M_{f}$ dla P91 i P92 i wybranych procesów spawania MMA, FCAW i SAW. Dla stopiwa T/P92 wyniki badań pokazują, że temperatura $M_{s}$ mieści się w zakresie $370 \div 390^{\circ} \mathrm{C}$, natomiast temperatura końca przemiany martenzytycznej $\mathrm{M}_{\mathrm{f}}$ leży w zakresie $105 \div 150^{\circ} \mathrm{C}$. Dla wyższych prędkości chłodzenia na poziomie $50^{\circ} \mathrm{C} / \mathrm{s}$ temperatura $\mathrm{M}_{\mathrm{f}}$ obniża się dodatkowo o $20 \div 40^{\circ} \mathrm{C}$ w porównaniu do $\mathrm{M}_{\mathrm{f}}$ dla typowej prędkości wynoszącej $20^{\circ} \mathrm{C} / \mathrm{s}$.

\section{Wybór parametrów spawania}

\section{Temperatura podgrzewania wstępnego i międzyściegowa}

Stal T/P92 wymaga podgrzewania wstępnego w celu wyeliminowania ryzyka wystąpienia pęknięć wodorowych. Pomimo większej skłonności do podhartowania stali P92 w porównaniu z P22 (2,25 Cr-1 Mo) wymagana temperatura podgrzania w celu wyeliminowania pęknięć wodorowych (na podstawie próby Tekkena) jest mniejsza od $\mathrm{T}_{\mathrm{p}}$ wymaganej dla P22 i nieznacznie większa od temperatury podgrzania wstępnego wymaganej dla P91, co zostało pokazane na rysunku 4 [10]. Może to być częściowo związane z niższą temperaturą przemiany martenzytycznej stali P92 i P91 oraz korzystnym wpływem niewielkiej ilości austenitu wtórnego wydzielanego już w zakresie temperatury podgrzania i międzyściegowej. Zalecana temperatura podgrzewania wstępnego wynosi $200^{\circ} \mathrm{C}$ bez względu na grubość spawanego materiału 


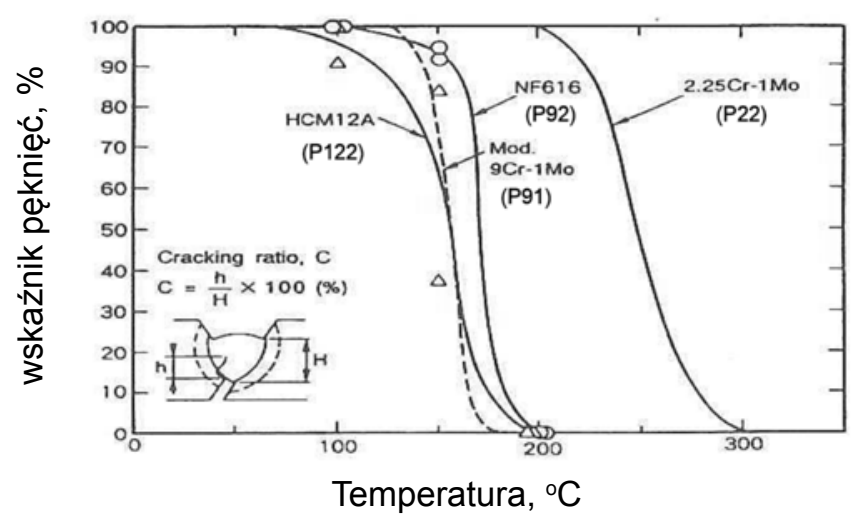

Rys. 4. Wyniki próby Tekkena, krzywe zależności wskaźnika liczby pęknięć C od temperatury podgrzewania wstępnego dla stali P92, P91, P22 [11]

Fig. 4. Y-groove test result of $P 92$ weld metal and comparison with other Cr-Mo steels, including P91, P92 and P122 [11]

dla wszystkich metod spawania z wyjątkiem metody TIG, dla której $T_{p}$ może być zdecydowanie niższa i w praktyce mieści się w zakresie $100 \div 150^{\circ} \mathrm{C}$. Jest to związane bezpośrednio ze znacznie niższym potencjałem adsorpcji wodoru w przypadku metody TIG. Wymagane jest, aby materiał każdego ściegu uległ częściowo przemianie martenzytycznej, dlatego temperatura międzyściegowa nie powinna przekraczać $300^{\circ} \mathrm{C}$ (w zakresie przemiany martenzytycznej $M_{s}-M_{f}$ od 105 do $390^{\circ} \mathrm{C}$ ). Poza tym, co jest bardzo ważne, dla nowo tworzonej struktury martenzytycznej każdy następny ścieg staje się ściegiem odprężającym dla poprzedniego.

\section{Kontrola prędkości chłodzenia po spawaniu}

Dla dużych prędkości chłodzenia temperatura końca przemiany martenzytycznej $M_{f}$ dla stopiwa $P 92$ może obniżyć się nawet do $105^{\circ} \mathrm{C}$, co oznacza, że przed przystąpieniem do wyżarzania odprężającego materiał spoiny powinien być schłodzony do temperatury poniżej $100^{\circ} \mathrm{C}$ w celu zapewnienia pełnej przemiany martenzytycznej. W przeciwnym razie, jeśli nie nastąpi pełna przemiana martenzytyczna stopiwa, resztki nieprzemienionego austenitu pozostające w materiale spoiny ulegną przemianie martenzytycznej dopiero po zakończonej obróbce cieplnej, co doprowadzi do wydzielenia się twardej struktury świeżego nieodprężonego martenzytu.

Jednym z elementów technologii spawania materiałów Cr-Mo jest dodatkowe wygrzewanie, tzw. odwodorowanie materiału spoiny w celu ograniczenia skłonności do pęknięć wodorowych w temperaturze otoczenia. Teoretycznie dla stali P92 odwodorowanie powinno być prowadzone w temperaturze nie mniejszej od temperatury podgrzania wstępnego, tj. ok. $200^{\circ} \mathrm{C}$ w czasie $24 \mathrm{~h}$, a nawet wyższej dla bardzo grubych elementów. Żeby odwodorowanie było efektywne, należy najpierw doprowadzić do pełnej przemiany martenzytycznej materiału spoiny przez schłodzenie spoiny do temperatury poniżej $100^{\circ} \mathrm{C}$, a następnie wygrzewanie w temperaturze ok. $200^{\circ} \mathrm{C}$ w celu umożliwienia dyfuzji wodoru z materiału spoiny. Jeśli nie nastąpi pełna przemiana, odwodorowanie staje się mniej skuteczne, co jest związane z większą rozpuszczalnością wodoru w strukturze austenitycznej, która częściowo występuje w zakresie temperatur $M_{s}-M_{f}$ i tym samym skłonnością do zatrzymywania wodoru w materiale spoiny. Innymi słowy, proces odwodorowania dla spoiny o pełnej strukturze martenzytycznej jest skuteczniejszy.

W praktyce dla elementów o grubości poniżej $50 \mathrm{~mm}$ wykonywanych ze stali P91 i P92 dodatkowe wygrzewanie w celu odwodorowania nie jest wymagane, tak jak w przypadku gatunków o większej zawartości węgla, tj. X20 (12CrMoV). Powolne chłodzenie do temperatury otoczenia elementów o grubości poniżej $50 \mathrm{~mm}$ nie przysparza w praktyce problemów. Trzeba jednak pamiętać, że elementy po spawaniu, ale jeszcze nieodpuszczone, wykazują dość dużą kruchość w temperaturze otoczenia, dlatego należy się z nimi obchodzić ostrożnie. Ponadto elementy o grubości powyżej $50 \mathrm{~mm}$ nie powinny być schładzane do temperatury poniżej $80^{\circ} \mathrm{C}$ [3].

\section{Dobór parametrów obróbki ciepInej po spawaniu}

Twardość zarówno spoiny, jak i SWC po spawaniu dla T/P92 mieści się w zakresie 400 450 HV, co oznacza, że obróbka cieplna - wyżarzanie odprężające - jest bezwzględnie wymagana niezależnie od grubości spawanych elementów. Przed przystąpieniem do obróbki cieplnej należy pamiętać o wcześniejszym schłodzeniu obrabianego elementu do temperatury poniżej $100^{\circ} \mathrm{C}$ w celu zapewnienia pełnej przemiany martenzytycznej $\left(\mathrm{M}_{\mathrm{f}} \sim 105^{\circ} \mathrm{C}\right)$.

Jak już wspomniano, maksymalna dopuszczalna temperatura obróbki cieplnej dla stali T/P92 jest ograniczona temperaturą $A_{c 1}$, która z kolei zależy od zawartości pierwiastków austenitotwórczych, głównie Ni i Mn. Ponadto zgodnie z wytycznymi ASME temperatura wyżarzania odprężającego nie powinna być mniejsza niż $730^{\circ} \mathrm{C}$. W praktyce jednak temperatura ta jest znacznie wyższa od zalecanego przez ASME minimum. Temperatura obróbki cieplnej podawana przez niektórych producentów materiałów podstawowych powinna mieścić się w zakresie $750 \div 780^{\circ} \mathrm{C}$ [3]. Dla zawartości pierwiastków $\mathrm{Ni}+\mathrm{Mn}$ poniżej $1,5 \%$ temperatura $A_{c 1}$ dla stopiwa $P 92$ wynosi $800 \div 815^{\circ} \mathrm{C}$ (rys. 1). W praktyce jednak temperatura wyżarzania odprężającego dla stopiwa P92 mieści się w zakresie $760 \div 780^{\circ} \mathrm{C}$. 


\section{Udarność stopiwa materiałów dodatkowych T/P92}

Wymagania dotyczące minimalnej udarności $w$ temperaturze otoczenia dla materiałów przeznaczonych do pracy w wysokiej temperaturze moga budzić pewne wątpliwości. W zakresie temperatury $500 \div 625^{\circ} \mathrm{C}$, właściwej dla P92, ryzyka wystąpienia pęknięć nie ma. W praktyce jednak większość elementów kotła, jak i sam kocioł, jeszcze przed uruchomieniem muszą zostać poddane próbom odbiorczym, w tym m.in. próbie ciśnieniowej, które przeprowadzane są $w$ temperaturze otoczenia. W zależności od przepisów temperatura próby ciśnieniowej wynosi $0 \div 30^{\circ} \mathrm{C}$. Dodatkowo duże ryzyko pęknięć występuje również na etapie montażu poszczególnych elementów kotła. $Z$ tego właśnie powodu formułowane są minimalne wymagania $w$ zakresie udarności w temperaturze otoczenia dla materiałów przeznaczonych do pracy w podwyższonej temperaturze. Nie ma norm klasyfikacyjnych dla materiałów dodatkowych P92. Dla materiałów P91 norma PN-EN 1599:1997 określa średnią udarność $w$ temp. $+20^{\circ} \mathrm{C}$ min. $47 \mathrm{~J}$ i nie mniej niż $38 \mathrm{~J}$ dla pojedynczej wartości. Możliwe, że w przyszłości również dla P92 zostaną przyjęte te same minimalne kryteria dla udarności. $Z$ drugiej jednak strony na podstawie informacji podawanych przez niektórych autorów minimalne warunki udarności $47 / 38 \mathrm{~J}$ mogą być trudne do spełnienia dla niektórych materiałów dodatkowych P92 i rzeczywistych warunków wyżarzania odprężającego [5]. Zarówno temperatura, jak i czas obróbki cieplnej dla stali P92 są wyższe od wymaganych dla P91, a mimo to często nie udaje się osiągnąć min. udarności na poziomie 47/38 J. Dlatego w praktyce dla P92 przyjmuje się kryteria udarności określone dla X20 (12CrMoV), tzn. min. $34 \mathrm{~J}$ i nie mniej niż $22 \mathrm{~J}$ w temp. $+20^{\circ} \mathrm{C}$.

\section{Wpływ parametrów spawania i obróbki cieplnej na udarność stopiwa}

Pomimo braku norm klasyfikacyjnych dla materiałów dodatkowych P92, podstawą doboru warunków spawania i obróbki cieplnej są przepisy AWS A5.5/A5.23. W laboratorium Metrode przeprowadzono wiele badań mających na celu określenie poziomu udarności w zależności od zastosowanych parametrów spawania i warunków obróbki cieplnej. W pierwszej kolejności wykonano cztery złącza próbne metodą MMA przy użyciu elektrod o średnicy $3,2 \mathrm{~mm}$ oznaczonych literami A-D. Dokonano pomiaru udarności stopiwa dla różnych parametrów spawania przy niezmiennych warunkach wyżarzania odprężającego $760^{\circ} \mathrm{C} / 5 \mathrm{~h}$. Wyniki zestawiono w tablicy III. Poza tym wykonano trzy złącza próbne metodą SAW przy różnych parametrach spawania i różnych warunkach obróbki cieplnej; wyniki zestawiono w tablicy IV.

$Z$ analizy wyników pierwszej serii badań (tabl. III) widoczne są pewne różnice $w$ udarności dla różnych parametrów spawania, chociaż nie tak duże, jakich się na początku spodziewano. Najniższe udarności uzyskano dla złącza A, wykonanego zgodnie z AWS, oraz złącza $C$ wykonanego przy użyciu szerokich i stosunkowo grubych ściegów. Warunki spawania

Tablica III. Wpływ parametrów spawania i sposobu układania ściegów na udarność stopiwa P92 wykonanego metodą MMA Table III. Effect of welding parameters and weld bead arrangement on toughness of P92 SMAW weld metal

\begin{tabular}{|c|c|c|c|}
\hline \multirow{2}{*}{ Złącze próbne - oznaczenie } & \multirow{2}{*}{$\begin{array}{c}\text { Przekrój poprzeczny } \\
\text { (liczba warstw i ściegów) }\end{array}$} & \multicolumn{2}{|c|}{ Udarność, Charpy V a } \\
\hline & & $+20^{\circ} \mathrm{C}$ & $0^{\circ} \mathrm{C}$ \\
\hline $\begin{array}{l}\text { A } \\
\text { Ściegi lekko zakosowe, dwa na warstwę, całkowita liczba } \\
\text { ściegów } 14 \text {. Średnia wysokość ściegu } \sim 1,8 \mathrm{~mm} \text {. } \\
\text { Średnia energia liniowa: } 1,2 \mathrm{~kJ} / \mathrm{mm}\end{array}$ & & $64(58) \mathrm{J}$ & $33(28) \mathrm{J}$ \\
\hline $\begin{array}{l}\text { B } \\
\text { Ściegi proste, trzy na warstwę, całkowita liczba ściegów } 18 . \\
\text { Średnia wysokość ściegu } \sim 2,1 \mathrm{~mm} \text {. Średnia energia liniowa: } \\
1,0 \mathrm{~kJ} / \mathrm{mm}\end{array}$ & & $77(66) \mathrm{J}$ & $48(41) \mathrm{J}$ \\
\hline $\begin{array}{l}\text { C } \\
\text { Ściegi pełne zakosowe, jeden ścieg na warstwę, całkowita } \\
\text { liczba ściegów } 4 \text {. Średnia wysokość ściegu } \sim 3,2 \mathrm{~mm} \text {. Średnia } \\
\text { energia liniowa: } 2,0 \mathrm{~kJ} / \mathrm{mm}\end{array}$ & & $63(56) \mathrm{J}$ & $43(36) \mathrm{J}$ \\
\hline $\begin{array}{l}\text { D } \\
\text { Ściegi pełne zakosowe, jeden ścieg na warstwę, całkowita licz- } \\
\text { ba ściegów } 10 \text {. Średnia wysokość ściegu } \sim 1,2 \mathrm{~mm} \text {. Średnia } \\
\text { energia liniowa: } 1,3 \mathrm{~kJ} / \mathrm{mm}\end{array}$ & $\exists$ & $71(56) \mathrm{J}$ & $46(42) \mathrm{J}$ \\
\hline
\end{tabular}


Tablica IV. Wpływ parametrów spawania i obróbki cieplnej na udarność i twardość stopiwa P92 wykonanego metodą SAW Table IV. Effect of welding parameters, weld bead arrangement and PWHT on impact toughness and hardness of P92 SAW weld metal

\begin{tabular}{|c|c|c|c|c|}
\hline \multirow{2}{*}{ Parametry spawania } & \multicolumn{4}{|c|}{$\begin{array}{l}\text { Parametry obróbki cieplnej, parametr P Larsona-Millera } \\
\text { Udarność Charpy'ego w } 20^{\circ} \mathrm{C} \text { średnia (minimalna), twardość }\end{array}$} \\
\hline & $\begin{array}{l}760^{\circ} \mathrm{C} / 4 \mathrm{~h} \\
(\mathrm{P}=21,29)\end{array}$ & $\begin{array}{l}770^{\circ} \mathrm{C} / 4 \mathrm{~h} \\
(\mathrm{P}=21,49)\end{array}$ & $\begin{array}{l}780^{\circ} \mathrm{C} / 4 \mathrm{~h} \\
(\mathrm{P}=21,70)\end{array}$ & $\begin{array}{l}760^{\circ} \mathrm{C} / 10 \mathrm{~h} \\
(\mathrm{P}=21,70)\end{array}$ \\
\hline $\begin{array}{l}\text { Złącze E: } 21 \text { ściegów } \\
\text { Śr. energia liniowa } 1,1 \mathrm{~kJ} / \mathrm{mm} \\
\text { Śr. wysokość ściegu: ok. 2,9 mm }\end{array}$ & $\begin{array}{l}31(27) \mathrm{J} \\
243 \mathrm{HV}\end{array}$ & $\begin{array}{l}26(22) \mathrm{J} \\
235 \mathrm{HV}\end{array}$ & $\begin{array}{l}28(24) \mathrm{J} \\
238 \mathrm{HV}\end{array}$ & $\begin{array}{l}34(29) \mathrm{J} \\
222 \mathrm{HV}\end{array}$ \\
\hline $\begin{array}{l}\text { Złącze F: } 17 \text { ściegów } \\
\text { Śr. energia liniowa } 1,8 \mathrm{~kJ} / \mathrm{mm} \\
\text { Śr. wysokość ściegu: ok. } 2,5 \mathrm{~mm}\end{array}$ & $\begin{array}{l}76(69) \mathrm{J} \\
241 \mathrm{HV}\end{array}$ & $\begin{array}{l}52(42) \mathrm{J} \\
238 \mathrm{HV}\end{array}$ & $\begin{array}{l}74(62) \mathrm{J} \\
233 \mathrm{HV}\end{array}$ & $\begin{array}{l}62(56) \mathrm{J} \\
219 \mathrm{HV}\end{array}$ \\
\hline $\begin{array}{l}\text { Złącze G: } 11 \text { ściegów } \\
\text { Śr. energia liniowa } 2,5 \mathrm{~kJ} / \mathrm{mm} \\
\text { Śr. wysokość ściegu: ok. } 3,6 \mathrm{~mm}\end{array}$ & $\begin{array}{l}51(34) \mathrm{J} \\
231 \mathrm{HV}\end{array}$ & $\begin{array}{l}52(46) \mathrm{J} \\
241 \mathrm{HV}\end{array}$ & $\begin{array}{c}86(71) \mathrm{J} \\
228 \mathrm{HV}\end{array}$ & $\begin{array}{c}73 \text { (49) J } \\
222 \mathrm{HV}\end{array}$ \\
\hline
\end{tabular}

zgodne z zaleceniami AWS zazwyczaj daja najlepsze wyniki udarności, co wynika z tego, że miejsce nacięcia karbu na próbce udarnościowej pokrywa się z obszarem nakładania się kolejnych ściegów, a to sprzyja pełniejszej rafinacji materiału spoiny. W tym przypadku dla złącza A (procedura AWS) nie uzyskano spodziewanej pełniejszej rafinacji obszaru spoiny jak dla złączy próbnych B i D. W przypadku złącza $D$ ściegi są szerokie i niskie, co sprzyja pełniejszej rafinacji materiału spoiny w poszczególnych ściegach. Zaskakująco wysokie wyniki udarności otrzymano również dla złącza próbnego $B$, w którym zastosowano po trzy dość grube proste ściegi na warstwę, dzięki czemu prawdopodobnie uzyskano pełniejszą rafinację całości materiału spoiny. Z praktycznego punktu widzenia użycie prostych ściegów, tak jak to miało miejsce dla złącza $B$, daje lepsze rezultaty od niskie i szerokie ściegi zaproponowane dla złącza $D$.

W celu określenia wpływu warunków wyżarzania odprężającego na udarność wykonano dwa złącza próbne metodą MMA, które poddano obróbce w temp. $760^{\circ} \mathrm{C}$ w czasie 2 i $5 \mathrm{~h}$. Średnia udarność dla złącza obrabianego krócej wynosiła $69 \mathrm{~J}$ w temperaturze $+20^{\circ} \mathrm{C}$, natomiast w przypadku dłuższego czasu obróbki średnia udarność $w$ temperaturze $+20^{\circ} \mathrm{C}$ wyniosła $93 \mathrm{~J}$. Można stwierdzić, że badania udarności dla wszystkich złączy próbnych dały wyniki pozytywne, zawsze powyżej minimalnej wartości $47 \mathrm{~J}$ wymaganej przez EN 1599 dla P91.

Wyniki badań złączy wykonanych łukiem krytym nie wykazują tak jednoznacznych zależności jak w przypadku złączy wykonanych metodą MMA (tabl. IV). Najniższą udarność uzyskano dla złącza E wykonanego przy użyciu najniższej energii liniowej spawania $(1,1 \mathrm{~kJ} / \mathrm{mm})$. W przypadku złączy wykonanych wyższymi energiami nie zaobserwowano większych różnic $w$ udarności zarówno dla średniej, jak i wysokiej wartości energii spawania
(1,8 i $2,5 \mathrm{~kJ} / \mathrm{mm})$. W przypadku złącza E wykonanego przy użyciu najniższej energii liniowej spawania obróbka cieplna po spawaniu miała niewielki wpływ na końcową udarność stopiwa. W tym przypadku bardzo trudno sformułować jednoznaczne wnioski, niemniej jednak zwykle wyższe temperatury wyżarzania oraz dłuższy czas obróbki skutkują mniejszą twardością materiału spoiny i zazwyczaj lepszą udarnością.

\section{Czasowa wytrzymałość na pełzanie - interpretacja wyników}

\section{Czasowa wytrzymałość na pełzanie dla stopiwa P92 i złączy spawanych}

Dla materiałów przeznaczonych do pracy w temperaturze $500 \div 625^{\circ} \mathrm{C}$ największe znaczenie mają wyniki prób czasowej odporności na pełzanie prowadzonych w zakresie temperatur właściwych dla badanego gatunku stali. Podczas eksperymentu przeprowadzono badania czasowej odporności na pełzanie stopiwa materiałów dodatkowych typu P92 wykonanych przy użyciu metod MMA, SAW, FCAW i TIG. W tym celu posłużono się zależnością czasowej wytrzymałości na pełzanie w funkcji parametru Larsona-Millera $P$ wyrażonego wzorem:

$$
P=K(C+\log t) \cdot 10^{-3}
$$

gdzie: $\mathrm{K}$ - temperatura pracy, $\mathrm{K} ; \mathrm{C}$ - stała materiałowa; $\mathrm{t}$ - czas pracy, $h$.

Na rysunku 5 zestawiono dane dla materiału podstawowego i dla stopiwa P92. Do analizy wyników przyjęto jednakową stałą Larsona-Millera $\mathrm{C}=36$. 


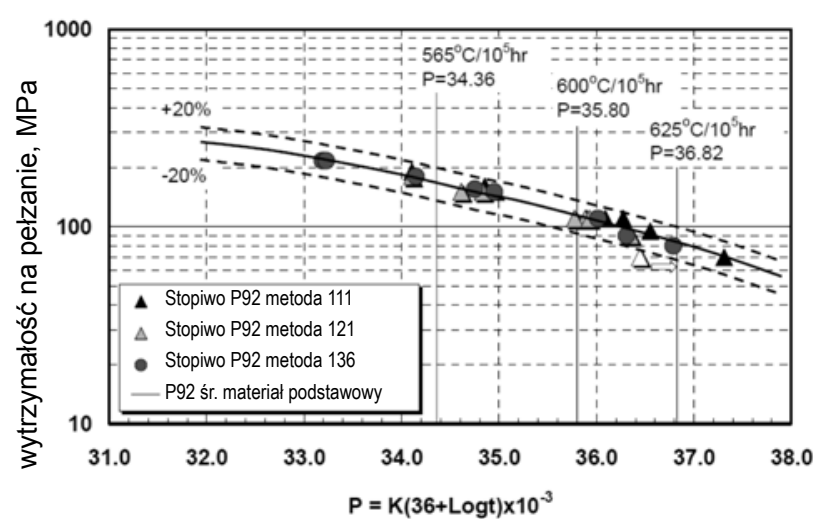

Rys. 5. Czasowa wytrzymałość na pełzanie na wykresie LarsonaMillera materiału podstawowego i stopiwa P92; stała C $=36$

Fig. 5. Larson-Miller plot of P92 base metal and weld metals with $\mathrm{C}=36$

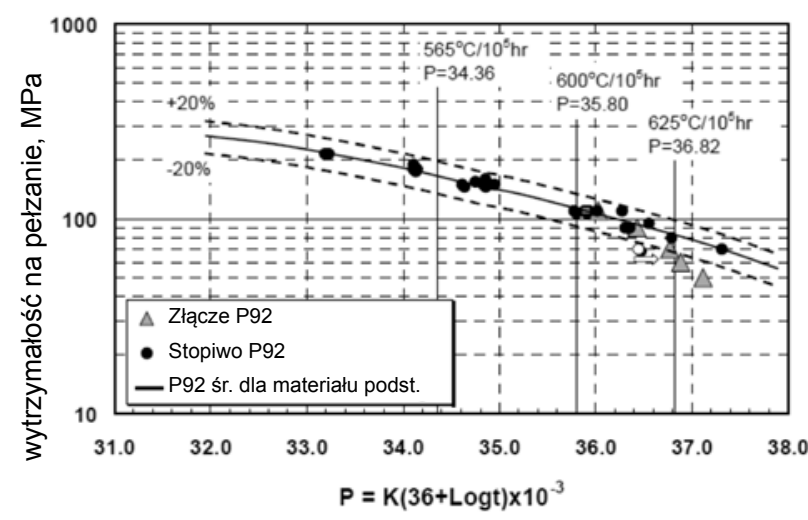

Rys. 6. Czasowa wytrzymałość na pełzanie dla złącza poprzecznego, stopiwa oraz materiału podstawowego P92; stała C = 36

Fig. 6. P92 transverse joint tests in comparison with all-weld metal and base material $(C=36)$

Na podstawie analizy wyników można zauważyć, że wartości długotrwałej odporności na pełzanie stopiwa mieszczą się w zakresie +/- $20 \%$ średnich wartości odporności na pełzanie materiału podstawowego.

W rzeczywistości dla materiałów o zawartości 9\% Cr odpornych na pełzanie, podczas prób czasowej wytrzymałości na pełzanie przeważnie zerwanie próbki następuje w strefie wpływu ciepła. Na rysunku 6 zestawiono wyniki uzyskane zarówno dla stopiwa, jak i złączy spawanych P92 (z próbką wyciętą w poprzek złącza, obejmującą spoinę, SWC oraz materiał podstawowy). Dla wyższych wartości parametru P Larsona-Millera (odpowiadających wyższej temperaturze pracy lub dłuższemu czasowi eksploatacji) wartości czasowej wytrzymałości na pełzanie stopniowo obniżają się poniżej obszaru -20\% średniej dla materiału podstawowego. Przyjmuje się, że jeśli wartości czasowej odporności na pełzanie stopiwa znajdują się we wspomnianym obszarze $+/-20 \%$ średniej czasowej odporności na pełzanie materiału podstawowego, to podczas próby czasowej odporności na pełzanie dla złącza spawanego zerwanie próbki nastąpi poza obszarem spoiny w SWC (rys. 6).

\section{Czasowa odporność na pełzanie stali P92 - interpretacja wyników}

Dzięki wyższej wytrzymałości na pełzanie stal P92 znajduje zastosowanie do produkcji bloków energetycznych na parametry nadkrytyczne pracujacych w temperaturze $600 \div 630^{\circ} \mathrm{C}$ i przy ciśnieniu 300 bar. W ostatnich latach wybudowano znaczną liczbę bloków na parametry nadkrytyczne o przeciętnej mocy $1000 \mathrm{MW}$, dzięki czemu wzrosło znacząco również zużycie stali P92. Należy zaznaczyć, że ze względu na relatywnie krótki okres eksploatacji bloków energetycznych wykonanych przy użyciu tego materiału nie są jeszcze dostępne wyczerpujące informacje na temat długotrwałej odporności na pełzanie stali P92. Jednak na przestrzeni ostatnich kilkunastu lat stosowania tej stali w przemyśle energetycznym opracowano i uaktualniono dane na temat jej czasowej wytrzymałości na pełzanie [17]. Różnią się one nieznacznie w stosunku do wartości obowiązujących $w$ momencie wprowadzania tego gatunku do eksploatacji $w$ połowie lat dziewięćdziesiątych. Przykładem mogą być dane opublikowane w 1999 r. przez ECCC (European Creep Collaborative Commission), na podstawie których wytrzymałość na pełzanie po $100000 \mathrm{~h}$ pracy $\mathrm{w}$ temperaturze $600^{\circ} \mathrm{C}$ wynosi $123 \mathrm{MPa}$ [18] i jest o $8 \mathrm{MPa}$ mniejsza od wytrzymałości podanej w 1999 r. Po kolejnych latach eksploatacji i badań nad pełzaniem stali P92 ta sama instytucja ECCC w 2005 r. opublikowała zaktualizowane dane na podstawie których długotrwała odporność, na pełzanie stali P92 po $100000 \mathrm{~h}$ pracy $\mathrm{w}$ temperaturze $600^{\circ} \mathrm{C}$ wynosi już tylko $113 \mathrm{MPa}$ [19]. Podobnie w przepisach ASME, część 2179-6 (2006) obniżono dopuszczalną wartość obliczeniową odporności na pełzanie w porównaniu do obowiązującej w 1994 r., i tak dla temperatury pracy $593^{\circ} \mathrm{C}$ została ona zredukowana do wartości $83 \mathrm{MPa}$ z początkowo obowiązujących $94 \mathrm{MPa}$ [20].

Bardzo wygodnym i użytecznym sposobem prezentowania danych na temat czasowej wytrzymałości na pełzanie jest wykres Larsona-Millera, głównie ze względu na możliwość zaprezentowania danych dla różnej temperatury pracy na jednym wykresie, pod warunkiem odpowiedniego dopasowania stałej materiałowej $\mathrm{C}$.

Do wyznaczania i późniejszej oceny wartości odporności na pełzanie stali P92 przez kilka lat do obliczeń przyjmowano wartość stałej Larsona-Millera w zakresie $C=32,6 \div 36[3,7,11,21]$. Jednak 


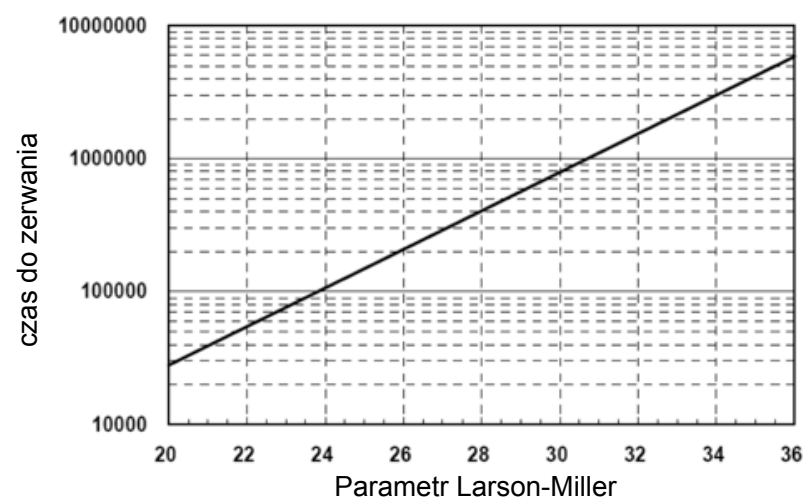

Rys. 7. Przewidywany okres do całkowitej utraty odporności na pełzanie w zależności od stałej materiałowej $\mathrm{C}$

Fig. 7. E911 transverse joint tests in comparison with all-weld metal and base material $(C=30)$

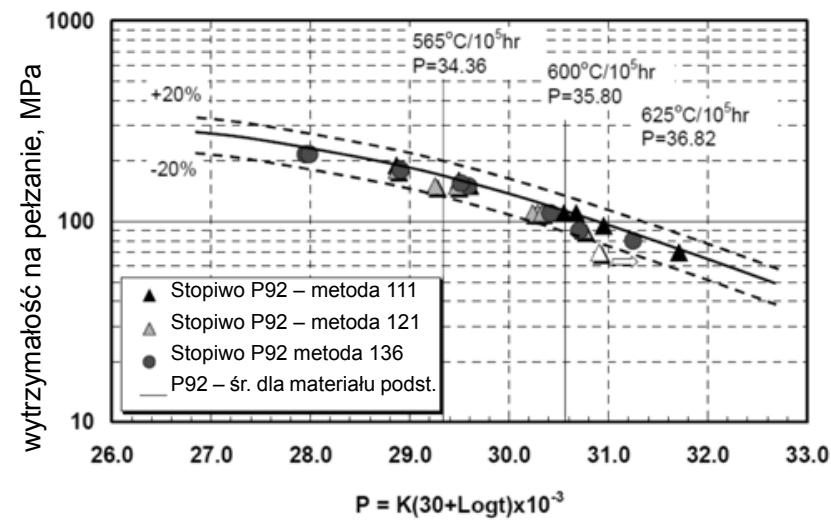

Rys. 8. Wartości czasowej wytrzymałości na pełzanie na wykresie Larsona-Millera materiału podstawowego i stopiwa P92; stała C $=30$ Fig. 8. Estimated duration of alloy strenght softening vs. Larson-Miller constant: $615^{\circ} \mathrm{C}$; tempeting temperature $760^{\circ} \mathrm{C}$

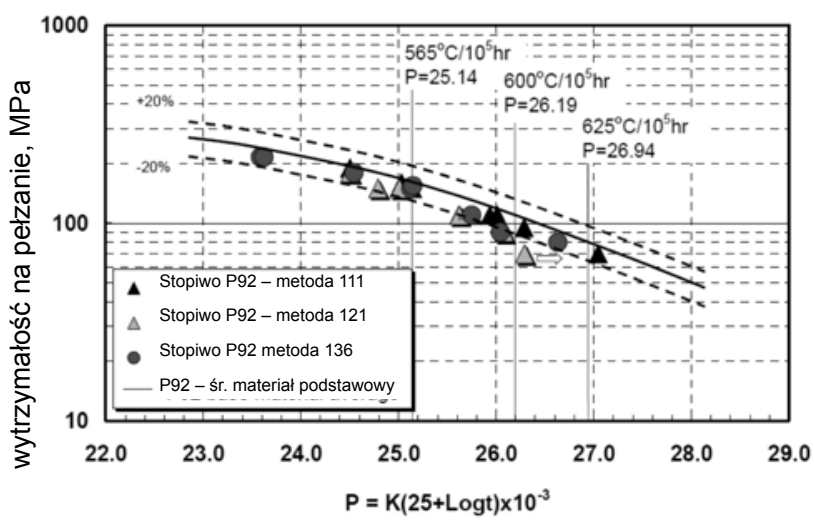

Rys. 9. Wartości czasowej wytrzymałości na pełzanie na wykresie Larsona-Millera materiału podstawowego i stopiwa P92; stała C $=25$ Fig. 9. Larson-Miller plot of P92 base metal and weld metals with $C=30$ fig. 10 Larson-Miller plot of P92 base metal and weld metals with $\mathrm{C}=25$ na podstawie zdobytych w ostatnich latach doświadczeń oraz aktualnych danych w zakresie długotrwałej odporności na pełzanie ustalono, że wyliczenia uzyskiwane przy użyciu stałej $\mathrm{C}=36$ prowadzą do przeszacowania wartości czasowej odporności na pełzanie. Na rysunku 7 pokazano przewidywany okres do całkowitej utraty odporności na pełzanie w zależności od stałej C [13,14]. Badania potwierdzają, że rzeczywisty okres do całkowitej utraty odporności na pełzanie następuje szybciej w porównaniu do wartości obliczeniowych wyznaczonych przy zastosowaniu stałej C w zakresie $30 \div 36$. W związku z tym do obliczeń zalecono wartość stałej $C$ poniżej 30. W kolejnych latach jeszcze dwukrotnie aktualizowano te informacje, w celu skorygowania wcześniejszych przeszacowanych wartości obliczeniowych odporności na pełzanie. W późniejszych projektach COST 522 i 536 do szacowania czasowej odporności na pełzanie nowej generacji stali o zawartości $9 \div 15 \% \mathrm{Cr}$, takich jak $\mathrm{C}(\mathrm{F}) \mathrm{B} 92$, zastosowano już znacznie niższą wartość stałej Larsona-Millera $C=25$ [22]. Bez wątpienia opisane powyżej doświadczenia doprowadziły do lepszego rozumienia i interpretacji zjawisk pełzania w stalach energetycznych, dzięki czemu publikowane obliczeniowe wartości czasowej odporności na pełzanie dla wspomnianych nowych gatunków stali $9 \div 15 \% \mathrm{Cr}$ są obarczone znacznie mniejszym błędem.

Na podstawie zdobytych doświadczeń, w szczególności ustalenia niższej od przewidywanej rzeczywistej czasowej odporności na pełzanie stali P92, konieczne stało się obniżenie parametrów pracy już eksploatowanych bloków energetycznych wykonanych $z$ tego gatunku, a w przypadku projektowania nowych boków do obliczeń przyjmuje się nieco większe grubości ścianek najważniejszych elementów kotła w celu dopasowania ich do pracy w zakresie parametrów nadkrytycznych temperatury i ciśnienia.

Na rysunkach 8 i 9 pokazano obliczeniowe wartości czasowej wytrzymałości na pełzanie materiału podstawowego i stopiwa P92 przy zastosowaniu niższej stałej Larsona-Millera $C=25$ i $C=30$. Porównując te wartości w danymi z rysunku $5(C=36)$ można zaobserwować, że dla stałej $C=25$ uzyskane wartości leżą poniżej obszaru $+/-20 \%$ wartości średniej dla materiału podstawowego (rys. 9), podczas gdy dla stałej $C=36$ wartości obliczeniowe wytrzymałości na pełzanie mieszczą się $w$ tym obszarze; nierzadko nawet mieszczą się ponad linią reprezentującą wartości średnie wytrzymałości na pełzanie materiału podstawowego. W tym przypadku zastosowanie niższej wartości stałej Larsona-Millera $C=25$ pozwala na uzyskanie pewnego marginesu bezpieczeństwa dla ekstrapolowanej wartości wytrzymałości na pełzanie. 


\section{Podsumowanie}

Jednym z najważniejszych materiałów podstawowych stosowanych do budowy bloków na parametry nadkrytyczne jest stal T/P92, która zapewnia lepszą długotrwałą odporność na pełzanie niż dotychczas stosowane stale chromowo-molibdenowe. Dostępne są również materiały dodatkowe do spawania odpowiadające składem chemicznym stali P92, przeznaczone zarówno do wykonywania elementów na etapie produkcji w warsztacie, jak również w warunkach montażu.

Zaprezentowano rzeczywiste wartości temperatury charakterystycznych przemian fazowych stopiwa P92. Temperatura $A_{c 1}$ stopiwa P92 mieści się w zakresie $800 \div 815^{\circ} \mathrm{C}$. Takie pierwiastki jak Ni, Mn i Co obniżają temperaturę $A_{c 1}$ przy czym wpływ kobaltu na obniżenie temperatury $A_{c 1}$, jest wyraźnie mniejszy i stanowi ok. $40 \%$ wpływu na $A_{c 1}$, jaki wykazują $\mathrm{Ni}$ i $\mathrm{Mn}$. W praktyce $\mathrm{w}$ celu zapewnienia odpowiedniej temperatury $A_{c 1}$ i tym samym skutecznej obróbki cieplnej konieczna jest ścisła kontrola zawartości pierwiastków obniżających temperaturę $A_{c 1}$ wg warunku
$\mathrm{Ni}+\mathrm{Mn}+0,4 \mathrm{Co}<1,5 \%$. Zalecana dla P92 temperatura obróbki cieplnej to ok. $760^{\circ} \mathrm{C}$, ale nie więcej niż $780^{\circ} \mathrm{C}$.

Temperatura początku przemiany martenzytycznej $\mathrm{M}_{\mathrm{s}}$ dla stopiwa $\mathrm{P} 92$ leży w przedziale $370 \div 390^{\circ} \mathrm{C}$. Najniższa zmierzona temperatura końca przemiany $M_{f}$ wynosi $105^{\circ} \mathrm{C}$, co - w celu zapewnienia pełnej przemiany martenzytycznej - wiąże się z koniecznością schłodzenia elementu do temperatury poniżej $100^{\circ} \mathrm{C}$ jeszcze przed przystąpieniem do właściwej obróbki cieplnej. Temperatura złącza podczas procesu spawania powinna mieścić się w zakresie $200 \div 300^{\circ} \mathrm{C}$.

Zarówno parametry spawania, jak i warunki obróbki cieplnej zostały tak dobrane, aby było możliwe uzyskanie optymalnych wartości udarności materiału spoiny w temperaturze otoczenia. W przypadku spawania elektrodami otulonymi najlepsze wyniki uzyskuje się przy zastosowaniu ściegów prostych o stosunkowo wysokiej energii liniowej.

\section{Literatura}

[1] H.J.R. Blum and J Hald: Development of High-efficiency USC Power Plants in Denmark, ConferenceProceedings: Advanced Steam Plant - New Materials and Plant Designs and their Practical Implications for Future CCGT and Conventional Power Stations, pp. 3-16, London, UK, 21-22 May 1997.

[2] W. Bendick, F. Deshayes, K. Harrmann and J.C. Vaillant: Conference Proceedings EPRI Conference on Advanced Heat Resistant Steels for Power Generation, San Sebastian, Spain, April 1998.

[3] D. Richardot, J.C. Vaillant, A. Arbab and W. Bendick: The T92/P92 Book, Vallourec \& Mannesmann Tubes, 2000.

[4] A. Arbab, J.C. Vaillant and B. Vandenberghe: Conference Proceedings: 3rd EPRI Conference on Advances in Material Technology for Fossil Power Plants, Edited by R. Viswanathan et al, pp. 99-112, London, UK, The Instituteof Materials, 2001.

[5] Metrode Products Limited: P92 Welding Consumables for the Power Generation Industry, Issue 2, August 2005.

[6] A. W. Marshall and Z. Zhang: COST 522 Project Final Report: Development of Welding Consumables for Advanced Cr-Mo Creep Resistance Steels, Metrode Products Limited, September 2003.

[7] H. Naoi, H. Mimura, M. Ohgam, H. Morimoto, T. Tanaka, Y. Yazaki and T. Fujita: NF616 Pipe Production and Welding Consumable Development; Conference Proceedings: The EPRI/National Power Conference - New Steels for Advanced Plant up to $620^{\circ} \mathrm{C}$, Edited by Metcalfe E, pp.8-29, London, UK, May 1995.

[8] H. Harrmann, J.C. Vaillant, B. Vandenberghe, W. Bendick and A. Arbab: The T91/P91 Book, 2nd Edition, Vallourec \& Mannesmann Tubes, 2002.

[9] F. Masuyama, T. Daikoku, H. Haneda, et al: United States Patent, No. 4799972, January 1989.

[10] J. P. Shingledecker: Oak Ridge National Laboratory (ORNL), private conversation, July 2007

[11] F. Masuyama and T. Yokoyama: NF616 Fabrication Trials in Comparison with HCM12A; Conference Proceedings: The EPRI/National Power Conference-New Steels for Advanced Plant up to 620C, Edited by Metcalfe E, pp 30-55, London, UK, May 1995.
[12] B. Swindeman: Presentation at the ASME Properties of Weldments Subgroup Meeting, Nashville, December 2001.

[13] K. Kimura: Long-term Creep Strength Assessment for Creep Strength Enhanced Ferritic Steels, Presentation at TG Creep Strength Enhanced Ferritic Steels, ASME Boiler Code Week, Los Angeles, USA, August 2005.

[14] M. Prager: Understanding Advanced Ferritic Alloys, Presentation at Seminar on High Temperature Alloys, Edmonton, Canada, November 2006.

[15] F. Abe: Metallurgy for Long-term Stabilization of Ferritic Steels for Thick Section Boiler Components in USC Power Plant at $650^{\circ} \mathrm{C}$, Conference Proceedings: Materials for Advanced Power Engineering 2006, Edited by J Lecomte-Beckers, M. Carton, F. Schubert and P.J. Ennis, Julich, Belgium, pp. 965-980, September 2006.

[16] N. Komai and F. Masuyama: Microstructural Degradation of the HAZ in $11 \mathrm{Cr}-9.4 \mathrm{Mo}-2 \mathrm{~W}-\mathrm{V}-\mathrm{Nb}-\mathrm{Cu}$ Steel (P122) during Creep, ISIJ International, Vol. 42 (2002), No. 12, pp. 1354-1370, 2002.

[17] Cases for ASME Boiler and Pressure Vessel Code, Case 2179, Approval Date: August 1994.

[18] ECCC, WG3.2: ECCC Data Sheets 1999, 1999.

[19] ECCC, WG3A: ECCC Data Sheets 2005, 2005.

[20] Cases for ASME Boiler and Pressure Vessel Code, Case 2179-6, Approval Date: August 2006.

[21] F. Masuyama: ASME Code Approval for NF616 and HCM12A, Conference Proceedings: The EPRI/National Power Conf. New Steels for Advanced Plant up to $620^{\circ} \mathrm{C}$, Edited by Metcalfe E, pp. 98-113, London, May 1995.

[22] M. Staubli: COST 522-Power Generation into the 21st Century; Advanced Steam Power Plant, COST 522 Steam Power Plant, Final Report, October 2003.

Tłumaczenie: Benedykt Ślązak 